\title{
Simulation of a small-scale electricity generation system from biomass gasification
}

\author{
V. Depoorter ${ }^{1}$, P. Olivella-Rosell ${ }^{1}$, A. Sudrià-Andreu ${ }^{1}$, Jordi Giral-Guardia ${ }^{1}$ and A. Sumper ${ }^{1,2}$ \\ ${ }^{1}$ Centre d'Innovació Tecnològica en Convertidors Estàtics i Accionaments (CITCEA-UPC), Universitat Politècnica de \\ Catalunya (UPC), C. Comte d'Urgell 187, Pl. 2. 08036 Barcelona, Spain \\ Phone:+34 9340167 27, e-mail: sumper@citcea.upc.edu \\ ${ }^{2}$ Electric Power Grids Area \\ Catalonia Institute for Energy Research \\ Jardins de les Dones de Negre, $12^{\text {a }} \mathrm{Pl}$, 08930 Barcelona (Spain)
}

\begin{abstract}
The following work has been developed in the scope of the cooperation project called Pôle Goundi. This project, coordinated by the NGO Misión y Desarrollo para Goundi, with the collaboration of the technology transfer centre CITCEA-UPC and the support of the CCD-UPC, aims to electrify Goundi, a village located in the South of Chad. In this sense, the construction of a small-scale biomass gasification power plant is planned. Since the installation of the power plant will be done by stages, the first step is to demonstrate its viability by installing and operating the first $20 \mathrm{~kW}$ of electrical power. For this, a complete commercial solution, mainly consisting of a multi-stage gasifier, an internal combustion engine and a synchronous generator, has been selected. Then, it has been modelled with Cycle-Tempo ${ }^{\circledR}$ and Matlab ${ }^{\circledR}$ simulation tools in order to analyze its operating parameters and performance. After a brief introduction about the aims and the scope of the project, this paper will proceed with a more detailed description of the system and the model and it will present some of the obtained results.
\end{abstract}

\section{Key words}

Biomass gasification, downdraft gasifier, spark-ignition engine, energy systems modelling, electricity production

\section{Introduction}

Chad, with a poverty index of $55 \%$, is one of world's poorest countries [1]. Such level of poverty, combined with the high percentage of population living in rural areas and the low energy consumption per capita, have made that most of people do not have access to modern forms of energy. With an electrical infrastructure limited to three small, not interconnected networks only $2.2 \%$ of Chadian households have access to electricity. In addition, the price of electricity is one of the highest worldwide. An energy sector as underdeveloped, with exorbitant electricity cost, represents a major barrier to the country's economic development [2]. In this scenario, the project Pôle Goundi has been launched in order to provide to Goundi a small-scale power plant and a distribution network which will spur its technological, economic and social activity.
The ultimate goal of the project is to reach a power capacity of $200 \mathrm{kVA}$ within a maximum of ten years and combine photovoltaic, solar thermal and biomass gasification technologies. However, the construction is expected to be done by stages, expanding gradually its capacity depending on the funding, the results obtained for each technology and the response of the people of Goundi. For the initial stage of the project power capacity has been limited to $25 \mathrm{kVA}$, which is enough to meet Pole's needs and the demand of a pump of $7.5 \mathrm{~kW}$ owned by the Goundi Water Company, the first consumer with whom an agreement has been reached,

After making a small study of alternatives, biomass gasification has been selected for the first stage of the project. On one hand, the sale of agricultural waste to generate electricity will incentivate the agricultural production, thus stimulating the local economy and increasing the availability of food for the people. On the other hand, the cultivation of biomass, the conditioning processes of the raw material and the operation of the power plant will generate jobs, enabling the reduction of unemployment rates. Moreover, the project also aims to prioritize two of the most disadvantaged groups in Goundi: women and the disabled. In this regard, the Association des Handicapés Physiques à Goundi will assist the recruitment and the training of employees [3].

\section{System description}

For the initial stage of the project, a $20 \mathrm{~kW}$ commercial system called Power Pallet ${ }^{\circledR}$ and produced by ALL Power Labs has been selected. Its main characteristics are shown in Table 1. It consists of a multi-stage gasifier, an internal combustion engine, a synchronous generator and a PCU (Process Control Unit) which controls the process and monitors some of its operating parameters. Figure 1 shows the external appearance of the system. This is a compact and technically advanced solution compared to other systems available on the market. 
The innovative design of the system includes several heat exchanges which transform waste heat into useful heat input for the process, improving its overall efficiency. On the other hand, the system operates at subatmospheric pressure in order to avoid gas leaks (carbon monoxide is toxic). Figure 2 shows a scheme of the gasification process, which is described in the following paragraphs.

Table I. - Power Pallet ${ }^{\circledR}$ specifications [4].

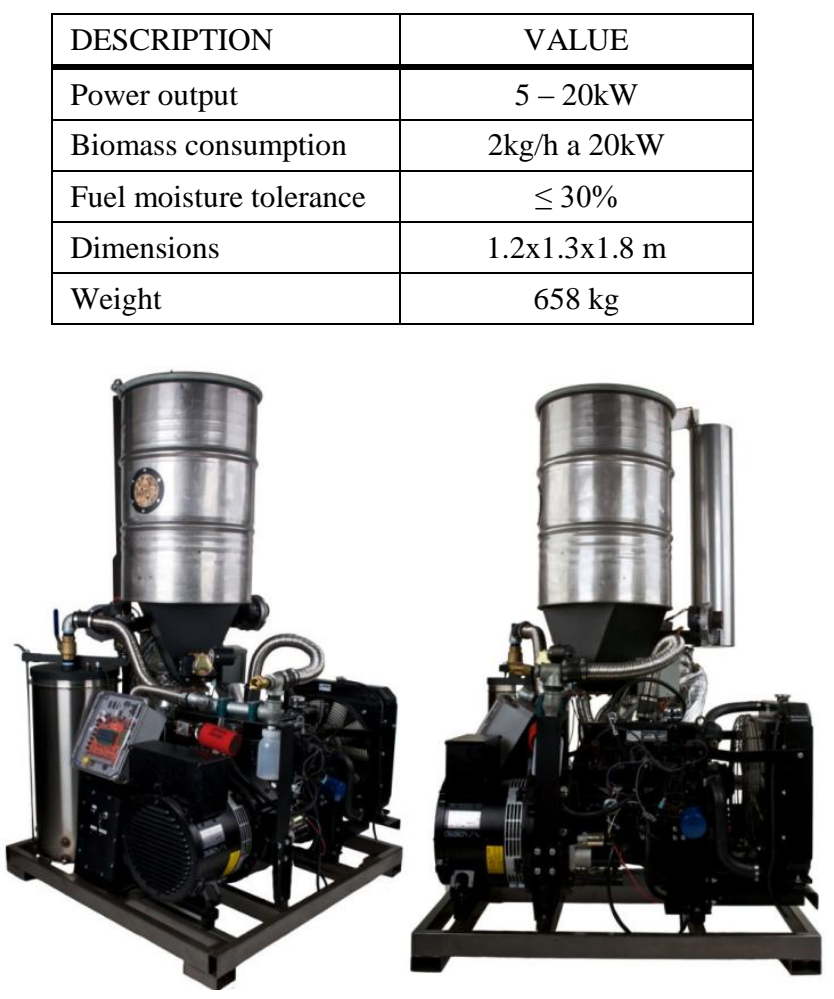

Fig. 1. Power Pallet ${ }^{\circledR}[4]$.

First, biomass is fed into the hopper which is sealed to maintain the low pressure. At the bottom of the hopper there is the drying zone where a heat exchange with the outgoing syngas removes the moisture contained in the biomass. Then, a screw transports the dried biomass inside the gasifier. The physical separation between the drying and the pyrolysis zones prevents the evaporation of water to compete with the heat required for the pyrolysis. In addition, the presence of water in the reactor would tend to agglomerate the tars and the soot into droplets, what would hinder tars removal by thermal cracking.

Power Pallet ${ }^{\circledR}$ system's gasifier is downdraft. Therefore, the pyrolysis takes place at the top of the reactor, the combustion at the middle and the reduction at the bottom. Typically, the heat required for pyrolysis proceeds only from combustion reactions, but in this case a double jacket heat exchanger allows the use of the engine's exhaust gases heat, thus increasing the efficiency of the process. The lines which transport the air to the oxidation zone also undergo a heat exchange with the outgoing syngas. Finally, the ash grate which lies below the reduction bell supports the charcoal in the reduction zone allowing ash and smaller char granules to pass through toward the bottom of the gasifier. Smaller granules normally fill the gaps between larger granules, increasing the density of the medium and obstructing the passage of gas. For this reason, ALL Power Labs has implemented a system that, depending on the pressure differences inside the reactor, shakes the grate in order to force small granules and ash to fall towards the bottom of the gasifier.

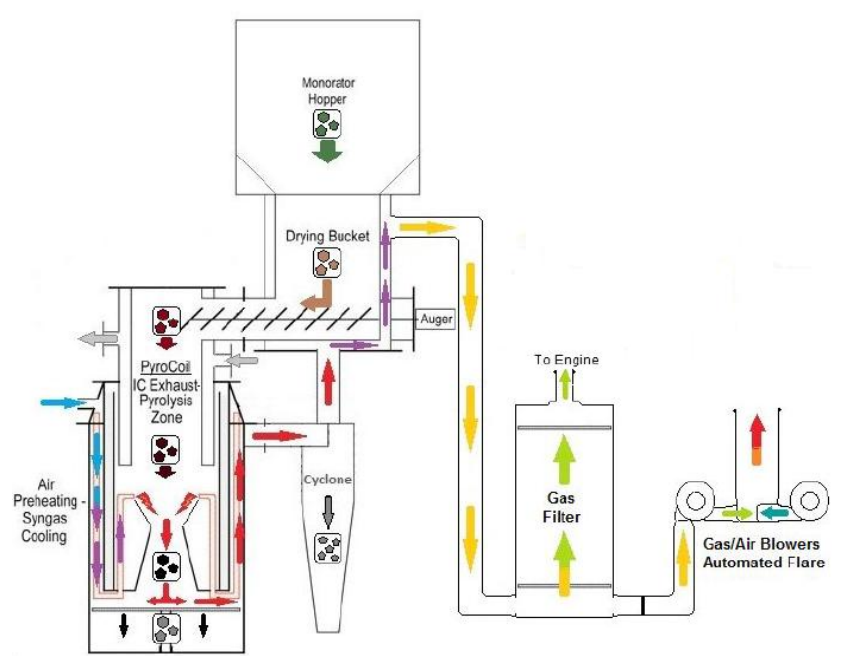

Fig. 2. Scheme of the gasification process [4].

When leaving the gasifier, the syngas passes through a cyclone that separates larger particles and condensates which may have been entrained in the flow. Then it can follow two paths depending on the operating regime of the system. During the steady state operation, the gas is introduced into the internal combustion engine after passing through a packed bed filter which definitively removes moisture and other impurities. In contrast, during the start-up, temperature in the oxidation zone is not high enough to destroy the tars. Therefore, as tars are very harmful to the combustion engine, gas is blown directly into a torch [5].

The internal combustion engine is a gasoline engine (spark-ignition engine) adapted to the use of gas. It has a servo control which acts as carburetor to mix the gas and the air in the proper proportions. The air-fuel ratio is adjusted through a control of the PCU and an oxygen sensor located in the exhaust gases flow which makes possible to know whether the mixture is rich or lean. To ensure the electrical $50 \mathrm{~Hz}$, it also has a governor which makes the engine turn at 1500rpm (synchronous generator has two pairs of poles).

\section{Model description}

In order to have a tool to analyze the operating parameters and the performance of the system, a model of the entire system has been developed. In addition, this tool will facilitate the design of other gasification equipment which would extend the power capacity of the generation plant in the future.

The system model is structured as shown in Figure 3 [6]. On one hand, the gasification process has been simulated using Cycle-Tempo ${ }^{\circledR}$ [7]. On the other hand, models of the 
internal combustion engine and the electrical system have been developed in Matlab ${ }^{\circledR} /$ Simulink $^{\circledR}[8]$.

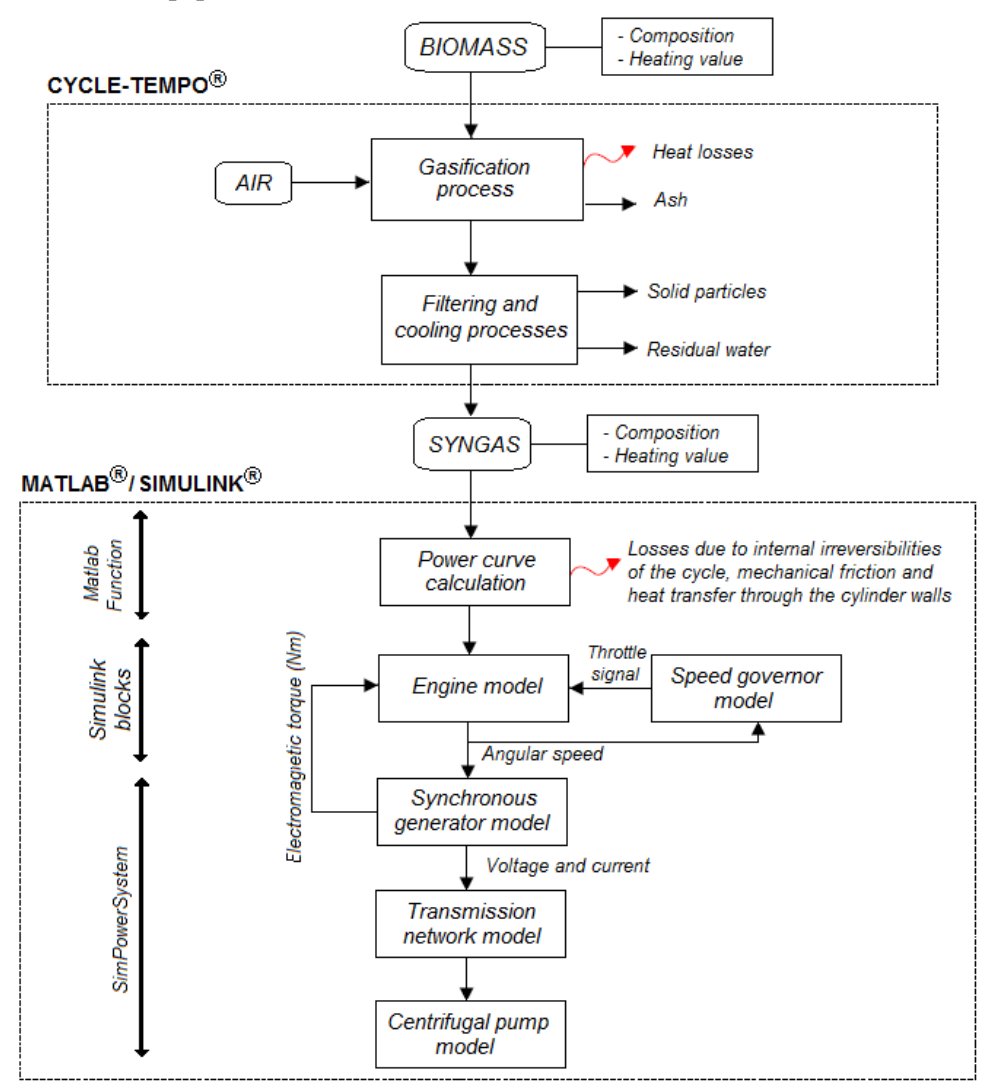

Fig. 3. Model structure

The model of the gasification process developed with Cycle-Tempo ${ }^{\circledR}$ is based on thermodynamic equilibrium. This means that the composition of the syngas is obtained from the minimization of Gibbs free energy, taking into account the chemical species which are present and the reaction temperatures and pressures. However, this type of models do not take into account the kinetics of the reactions (conversion rates and residence times of reactants), because it would considerably complicate its application to biomass gasification processes, in which large number of reactions are involved [9]. While it is true that thermodynamic equilibrium models often overestimate a bit the contents of $\mathrm{H}_{2}, \mathrm{CO}$ and $\mathrm{H}_{2} \mathrm{O}$ and underestimate the amount of $\mathrm{CH}_{4}$, in the case of downdraft gasifiers they are quite accurate [10]. In addition, as recommended by some researchers, the gasification process has been simulated through several reactors with intermediate separations of certain components in order to achieve close results compared to experimental (Figure 4) [11][12].

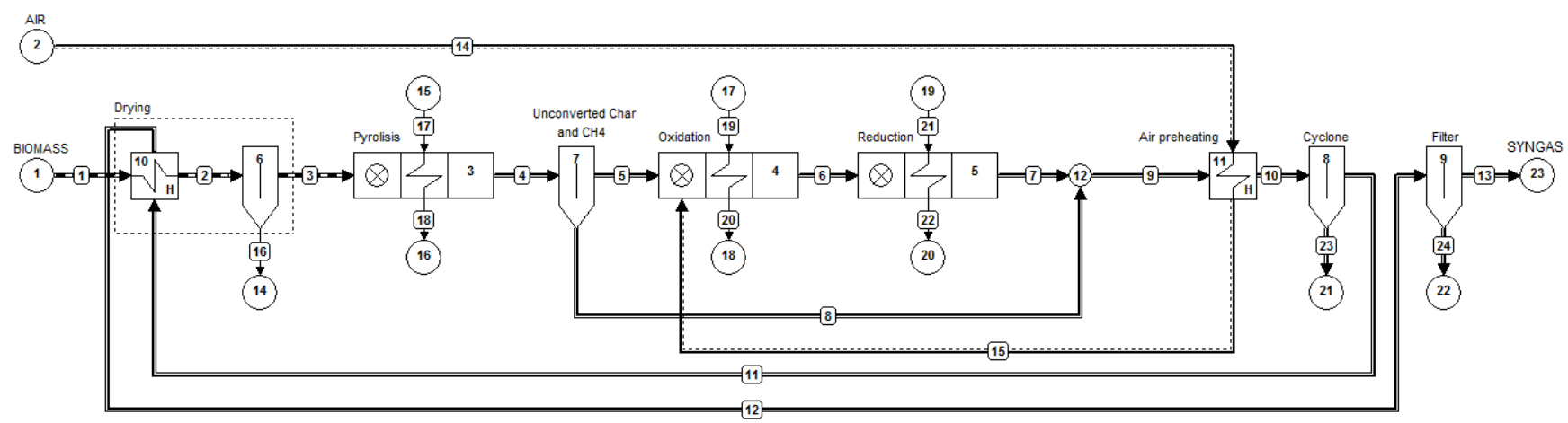

Fig. 4. Simulation flow sheet of gasification process in Cycle-Tempo ${ }^{\circledR}$

Once the gasification process has been simulated, a Matlab $^{\circledR}$ function enables the estimation of the engine's power curve when operating with syngas. Since it is a spark ignition engine, the power curve calculation is based on the Otto cycle, considering three types of losses: internal irreversibilities of the cycle, mechanical friction and heat transfer through the cylinder walls [13][14]. In order to estimate the performance of the Otto cycle, the effect of variable specific heats has also been taken into account with a linear approximation of this parameter as a function of the temperature [15][16]. 
Then, the new power curve has been implemented in the dynamic model developed with Simulink ${ }^{\circledR}$ (Figure 5). This model simulates the behaviour of the motorgenerator set with the equation of rotational motion. On one hand, the maximum brake torque delivered by the engine is derived from the power curve and is modulated by the Throttle signal, which corresponds to the opening of the throttle valve located in the intake. Its value is comprised between 0 and 1 and is controlled by the speed governor (PID regulation) in order to maintain the motorgenerator set at $1500 \mathrm{rpm}$. On the other hand, considering that the friction is negligible in the electric generator, the resistive torque the engine has to overcome is the electromagnetic torque of the synchronous machine.

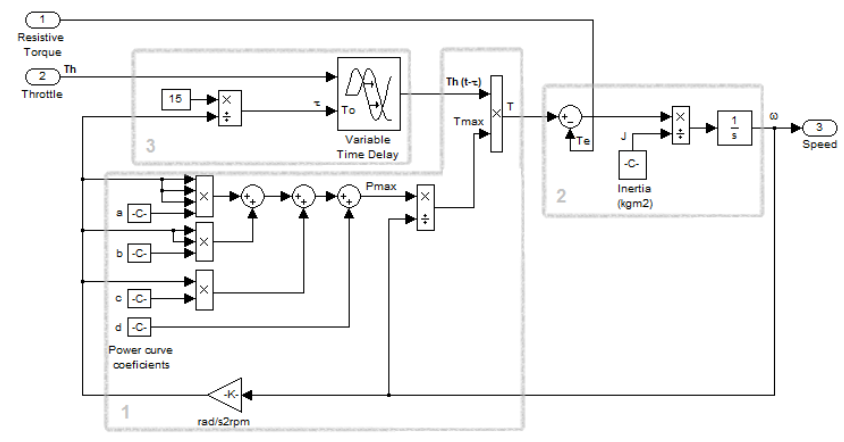

Fig. 5. Model of the engine (Matlab/Simulink $\left.{ }^{\circledR}\right)$

Finally, since the connection between the combustion engine and the synchronous generator is direct (without a gearing box), the input signal for the generator is the angular speed of the engine. Electrical system elements (synchronous generator, transmission line and centrifugal pump) have been simulated with blocks from the toolbox SimPowerSystems ${ }^{\circledR}$.

\section{Results and discussion}

First of all, the gasification process has been simulated for two types of biomass: corn cob hearts and corn stalk. The model has allowed the analysis of the composition and the calorific value of the producer gas as a function of the airfuel ratio $\mathrm{x}_{\mathrm{OF}}$ (Figures 6 and 7). The results have shown that there is a determined value of $\mathrm{x}_{\mathrm{OF}}$ (1.8 for corn cob hearts and 1.6 for corn stalk) at which the presence of $\mathrm{CO}$ and $\mathrm{H}_{2}$ is greatest, i.e. the heating value is maximised. Below this amount of air, the presence of char $\mathrm{C}(\mathrm{s})$ demonstrates that part of the biomass is not gasified, leading to a drop of the calorific value of the gas. On the other hand, higher presence of air increases the formation of $\mathrm{CO}_{2}$ and $\mathrm{H}_{2} \mathrm{O}$ at the expense of consuming more $\mathrm{CO}$ and $\mathrm{H}_{2}$, leading to a rise of the gasification temperature and a decrease of the heating value of the producer gas. Therefore, ideally the system should operate at these points.

However, to prevent the tars to damage the spark ignition engine, the combustion zone of the gasifier has to reach the temperature at which they are destroyed by thermal cracking. For this reason, to simulate the steady state behaviour of the system the value of $\mathrm{x}_{\mathrm{OF}}$ has been set in order to have $1000^{\circ} \mathrm{C}$ in the combustion zone of the downdraft gasifier [6]. The obtained results for both fuels are shown in the Table 2. According to the definition of the cold gas efficiency (Equation 1), corn cob hearts gasification performs better, with a efficiency of $81.34 \%$ against $74.82 \%$ for corn stalk gasification [17].

$$
\eta_{c g}=\frac{\dot{m}_{g a s} \cdot L H V_{g a s}}{\dot{m}_{\text {biomass }} \cdot L H V_{\text {biomass }}}
$$

This is mainly due to the fact that corn cob hearts need more air to reach the combustion temperature of $1000^{\circ} \mathrm{C}$, what makes the producer gas energetically poorer, but what is outweighed by a greater mass flow. On the other hand, the high ash content in corn stalk also reduces its gasification efficiency. Finally, it must also be acknowledged that the fibrous nature of stalk may hinder its gasification.
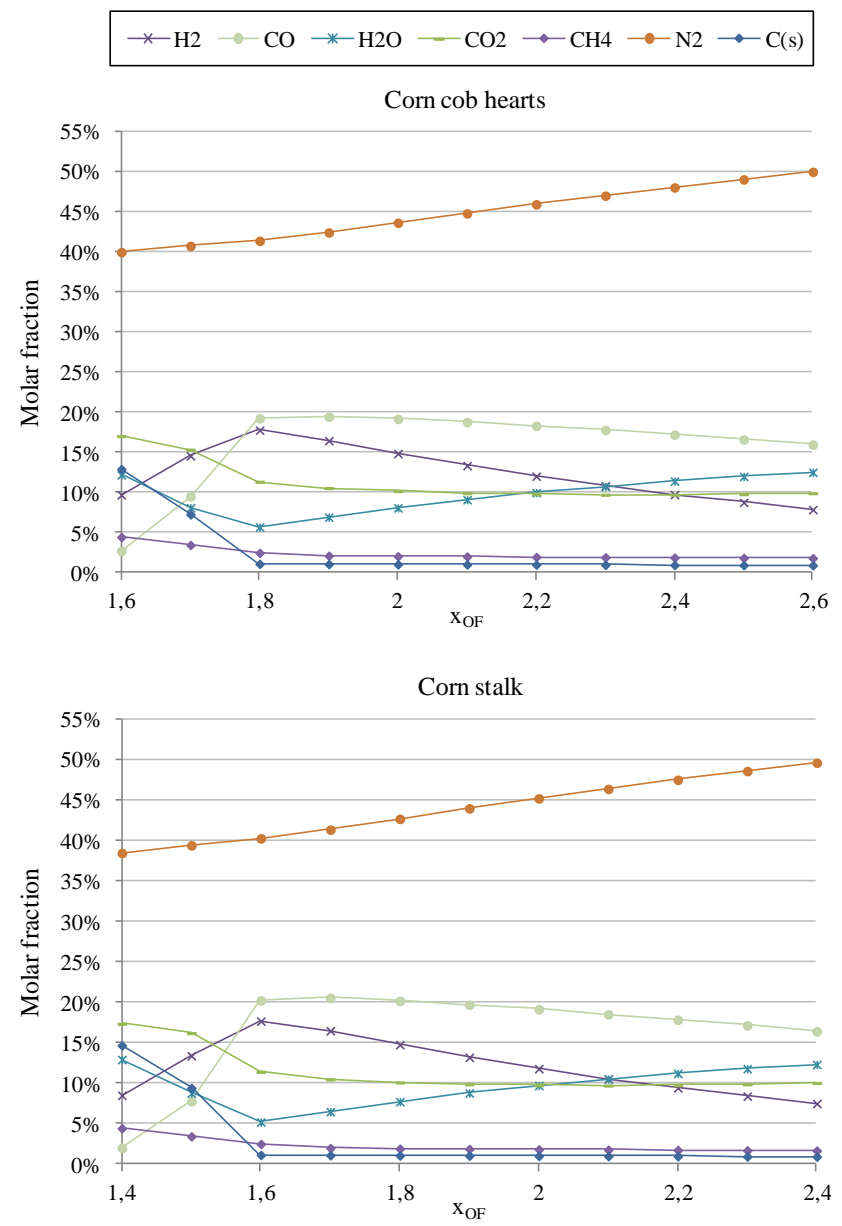

Fig. 6. Producer gas composition at the gasifier outlet

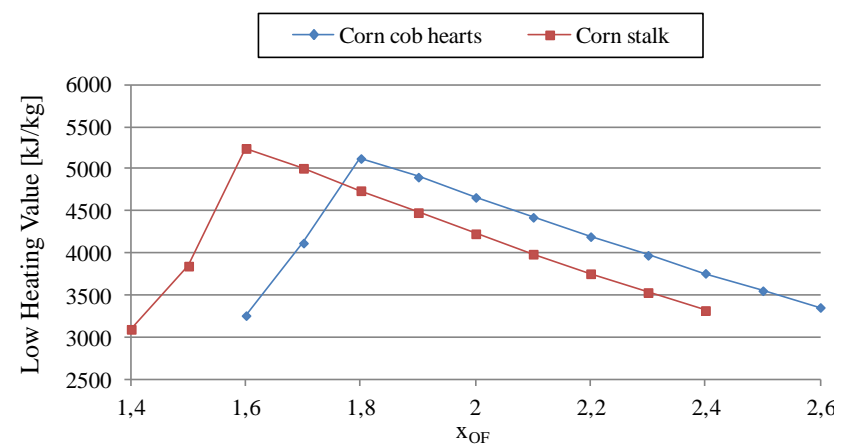


Fig. 7. Low heating value of the producer gas

Table II. - Characteristics of the produced syngas

\begin{tabular}{|l|c|c|}
\hline $\begin{array}{l}\text { SYNGAS } \\
\text { CARACHTERISTICS }\end{array}$ & $\begin{array}{c}\text { CORN COB } \\
\text { HEARTS }\end{array}$ & $\begin{array}{c}\text { CORN } \\
\text { STALK }\end{array}$ \\
\hline Biomass consumption $(\mathrm{kg} / \mathrm{h})$ & 22,00 & 22,00 \\
\hline Biomass LHV $(\mathrm{kJ} / \mathrm{kg})$ & 14640,00 & 14880,00 \\
\hline $\mathrm{x}_{\mathrm{OF}}(\mathrm{kg}$ air/kg biomass $)$ & 1,96 & 1,76 \\
\hline Oxidation temperature $\left({ }^{\circ} \mathrm{C}\right)$ & 1002,00 & 1005,00 \\
\hline $\mathrm{Molar}$ fraction $(\%$ mol $)$ & & \\
$\mathrm{H}_{2}$ & $17,05 \%$ & $17,05 \%$ \\
$\mathrm{H}_{2} \mathrm{O}$ & $0,00 \%$ & $0,00 \%$ \\
$\mathrm{~N}_{2}$ & $47,48 \%$ & $46,48 \%$ \\
$\mathrm{AR}$ & $0,56 \%$ & $0,55 \%$ \\
$\mathrm{CO}$ & $11,35 \%$ & $11,31 \%$ \\
$\mathrm{CH}_{4}$ & $2,31 \%$ & $2,17 \%$ \\
$\mathrm{CO}$ & $21,24 \%$ & $22,45 \%$ \\
\hline Producer gas mass flow $(\mathrm{kg} / \mathrm{h})$ & 55,05 & 50,52 \\
\hline LHV syngas $(\mathrm{kJ} / \mathrm{kg})$ & 4758,74 & 4848,32 \\
\hline Cold-gas efficiency, $\eta_{c g}$ & $81,34 \%$ & $74,82 \%$ \\
\hline Ash and residual charcoal & 0,90 & 1,65 \\
production $(\mathrm{kg} / \mathrm{h})$ & & \\
\hline
\end{tabular}

Once the heating value of syngas has been determined, it has been possible to calculate the power curve of the engine. As shown in the Figure 8, in its nominal operating point $(1500 \mathrm{rpm})$, the brake power of the engine is 21.64 $\mathrm{kW}$ with and the efficiency is $30.09 \%$. Should be remembered that this is the maximum power the engine can deliver at this speed, but it is then modulated by the action of the throttle (controlled by the speed governor).

\section{Direct on-line starting}
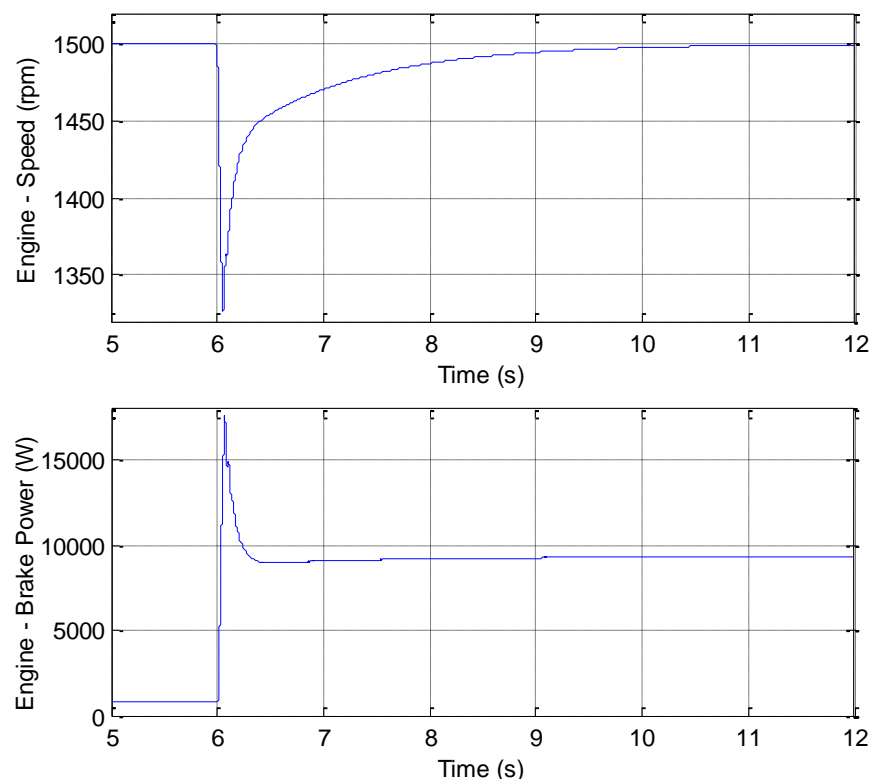
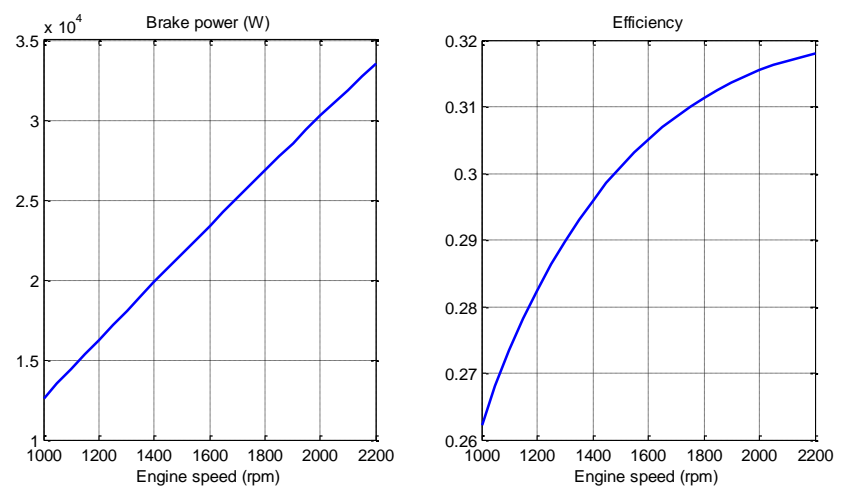

Fig. 8. Brake power and efficiency curves of the engine

Finally, two types of disturbances have been simulated with the dynamic model of Simulink ${ }^{\circledR}$ : the switch on of the centrifugal pump and a momentary reduction of the heating value of the syngas. On one hand, simulation results (Figure 9) show that direct on-line starting would cause a frequency drop of $11.6 \%$, a voltage drop of $21.2 \%$ followed by a surge of $22.1 \%$ and a start-up current in the pump of 6.2 times its nominal value. For this reason, a softer starting mode has been necessary. In this sense, simulations have shown that a star-delta start would reduce the frequency drop to $6.67 \%$, the voltage drop and the voltage surge to $8.85 \%$ and $6.19 \%$ respectively and starting currents in the pump to 4.4 times its nominal value. On the other hand, the simulations have shown that a reduction of $20 \%$ of the heating value of the gas during 2 seconds would not cause significant voltage and current variations and that the frequency drops would be only of $1.3 \%$.
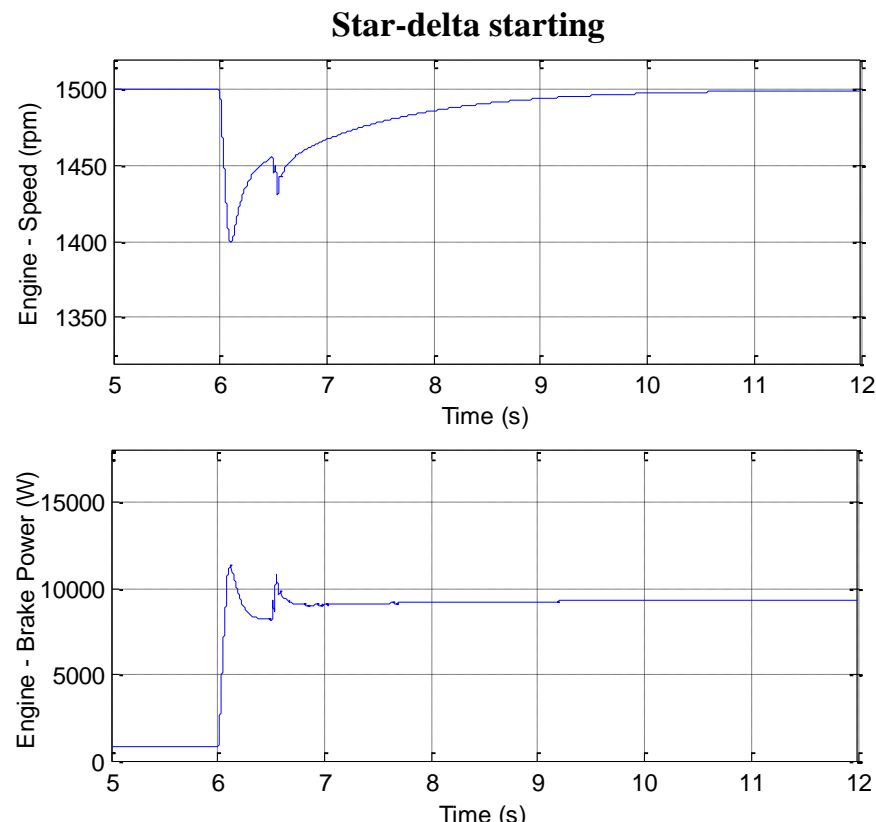

Fig. 9. Dynamic response of the engine to direct on-line starting (left) and star-delta starting (right) of the pump 

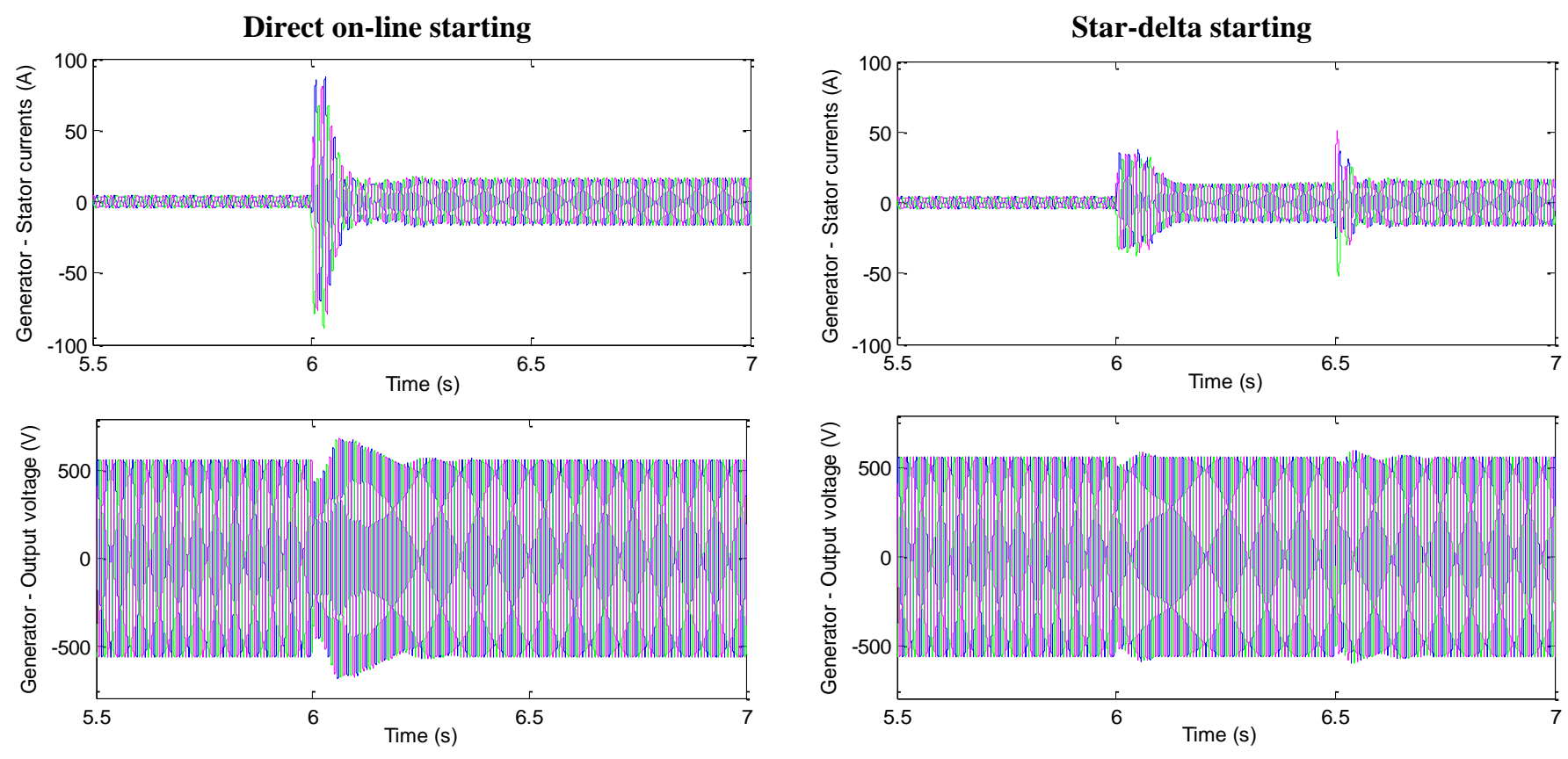

Fig. 10. Dynamic response of the generator to direct on-line starting (left) and star-delta starting (right) of the pump. (Continuation)

\section{Conclusions}

The model presented in this paper constitutes a complete simulation tool to assist the design and the analysis of new electricity generation systems from biomass gasification with internal combustion engines. Up to now the model has been validated with published data from specialized literature, but the Power Pallet ${ }^{\circledR}$ system will be tested in order to get further information about its operation and enable the adjustment of simulation parameters to obtain simulation results as close as possible to reality.

\section{References}

[1] Intermon Oxfam, "Chad," 2013. [Online]. Available: http://www.intermonoxfam.org/. [Accessed January 2013].

[2] REN 21 y REEEP, "Energy Profile Chad," 2010. [Online]. Available: http://www.reegle.info/countries/chad-energyprofile/TD\#renewable_energy. [Accessed January 2013].

[3] Misión y Desarrollo para Goundi, "Goundi," 2013. [Online]. Available:

http://www.misionydesarrolloparagoundi.com. [Accessed January 2013].

[4] ALL Power Labs, "GEK Gasifier," 2013. [Online]. Available: http://www.gekgasifier.com/. [Accessed Febrero 2013].

[5] J. Martínez, K. Mahkamov, R. Andrade and E. Silva Lora, "Syngas production in downdraft biomass gasifiers and its application using internal combustion engines," Renewable Energy 38, pp. 1-9, 2012.

[6] D. Vera, B. de Mena, F. Jurado and G. Schories, "Study of a downdraft gasifer and gas engine fueled with olive oil industry wastes," Applied Thermal Engineering, pp. 119. 129,2013

[7] TU Delft, "Cycle-Tempo Software," 2013. [Online]. Available: http://www.cycle-tempo.nl/. [Accessed 2013
February].

[8] I. The MathWorks, «Simulink,» 2013. [En línea]. Available: http://www.mathworks.es/products/simulink/. [Último acceso: Marzo 2013].

[9] R. Toonssen, "Sustainable Power from Biomass: Comparison of technologies for centralized or decentralized fuel cell systems," Delft, 2010.

[10] T. Reed and A. Das, Handbook of Biomass Downdraft Gasifier Engine Systems, Golden: Solar Energy Research Institute (U.S. Department of Energy), 1988.

[11] D. Panopoulos, E. Fryda, J. Karl, S. Poulou and E. Kakaras, "High temperature solid oxide fuel cell integrated with novel allothermal biomass gasification: Part I: Modelling and feasibility study.," Journal of Power Sources 159, p. 570-585, 2006.

[12] C. Altafini, P. Wander and R. Barreto, "Prediction of the working parameters of a wood waste gasifier through an equilibrium model," Energy Conversion and Management 44, pp. 2763-2777, 2003.

[13] P. Curto-Risso, A. Medina and A. Calvo Hernández, "Theoretical and simulated models for an irreversible Otto cycle," Journal of Applied Physics 104, p. 094911, 2008.

[14] M. Mozurkewich and R. S. Berry, "Optimal paths for thermodynamic systems: The ideal Otto cycle," Journal of Applied Physics, pp. 34-45, 1982.

[15] R. Ebrahimi, "Effects of Variable Specific Heat Ratio on Performance of an Endoreversible Otto Cycle," Acta Physica Polonica Vol.117 Num. 6, pp. 887-891, 2010.

[16] Y. Ge, L. Chen and F. Sun, "Finite-time thermodynamic modelling and analysis of an irreversible Otto-cycle," Applied Energy, p. 618-624, 2008.

[17] P. Basu, Biomass Gasification and Pyrolysis, Kinglington: Elsevier Inc., 2010. 